\title{
カナダ国家研究会議 工業材料研究所 (CNRC/IMI)
}

田上秀 一*

\section{1.はじめに}

小生は, 文部科学省在外研究員として “Conseil national de recherches Canada, Institut des matériaux industriels (CNRC/IMI)”にお世話になる機会を得た。この名称はフ ランス語表記であり，英語では “National Research Council Canada, Industrial Materials Institute (NRC/IMI)” と 書く. 英語表記のほうが, 読者にはなじみがあると思う。 CNRC/IMI は，モントリオールの中心からセントローレ ンス川を挟んで北西へ約 $10 \mathrm{~km}$, ケベック州の Boucherville という閑静な French speaking townにある.

$\mathrm{CNRC} / \mathrm{IMI}$ の歴史, 研究グループ, 設備などの全体的 な概要については本誌1)で紹介されているので, 本稿では, 小生がお世話になった研究グループ “Groupe Composite Polyméres/Polymer Composite Group”について紹介する.

\section{Polymer Composite Group の概要}

既報1)と重なる部分もあるかもしれないが， CNRC/IMI について，まず簡単に触れておく. 図 1 (a) は Boucherville にある CNRC/IMI の建物の写真である. 写真中の Prototyping Laboratory は増築された研究スペースで昨年完成 した.また, Project office and laboratory space に新たな 建物の増築を行う計画があるとのことである. CNRC/IMI は, “Materials and Processes” と “Process Modelling and Instrumentation”の 2 つテクニカルセクションがある. 最近, 3 番目のセクションとして Aluminium Technologies Centre が，5年間で約 5700 万カナダドルをかけて設立さ れた。そのセンターはケベック州の Saguenay-Lac-St-Jean 地区にあるアルミニウムプラントの近くにあり, 建物（図 1(b)）は Université de Québec á Chicoutimi (UQAC) の キャンパス内に現在建設中である。詳細はウェブサイト 〈http : //www.imi.cnrc-nrc.gc.ca/english/〉を参照された い. 表 1 はIMI の研究グループをまとめたものである. この表の上段はフランス語表記, 下段は英語表記である. CNRC/IMI には, Directorによって管理されている3つ のテクニカルセクションがあり, その下に Group Leader

\footnotetext{
"Tanoue, Shuichi

福井大学工学部材料開発工学科

福井市文京 3-9-1（广910-8507)

2003.1.27 受理
}

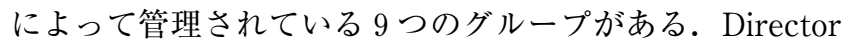
と Group Leader はマネージャーを兼ねた研究員である. IMI では他に, 研究員, 技官, 事務職員が働いている.

Polymer Composite Groupは Materials and Processes セクションに属して抢り, Group LeaderはJohanne Denault 博士である.このグループには 6 名の研究員, 6 名 の技官, そして研究に従事している学生やポスドクが若干 名所属している. CNRC/IMI では, 研究員は特定のプロ ジェクトに関する仕事をして㧍り，その任務は，調査，実 験デー夕の評価, 論文や特許の出版, 技術や成果の工業へ の還元などを通じて, 時代にあった研究を実施することで ある. 実験サンプルの準備, 機器の操作, 資料の測定など の実験そのものは, 研究員が直接行うこともあるが, 主に 技官の仕事である. CNRC/IMI で働く技官は, 各研究グ ループに数名配属されており, 3 年間の Technical College における教育と 1 年間の実務経験を経ているので, 優れた 行動力と高い知識を兼ね備えている. そのため, 研究員に は研究とプロジェクトの実施に専念できる環境が整ってい る.ところで, 表 1 で示す研究グループの陣容㧍よびメン バーは, 研究テーマやプロジェクトに応じて変わる.

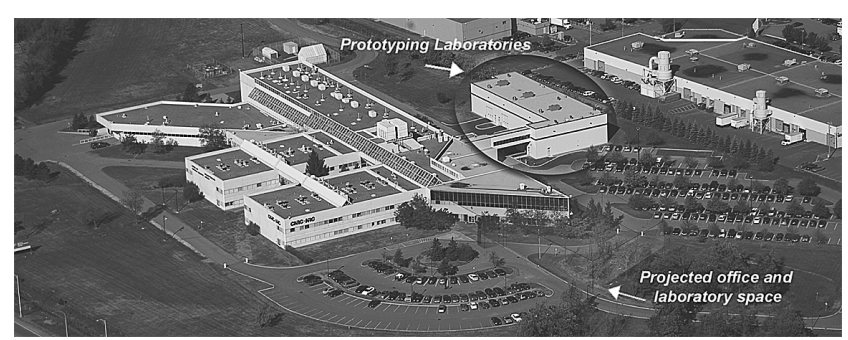

(a)Boucherville地区

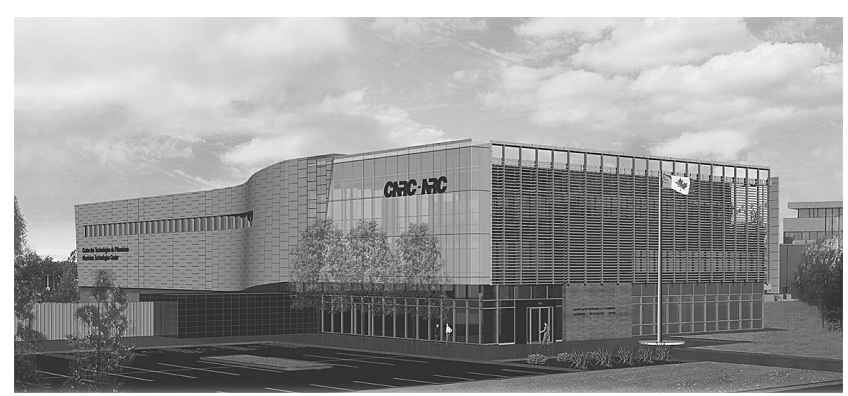

(b) Alminium Technologies Centre (完成予想図) 
表 $1 \mathrm{CNRC} / \mathrm{IMI}$ における研究グループ(2002 年 12 月 5 日現在)

\begin{tabular}{l|l}
\hline \multicolumn{1}{c|}{ Technical Sections } & \multicolumn{1}{c}{ Research Groups } \\
\hline \multirow{4}{*}{$\begin{array}{l}\text { Matériaux et procédés } / \\
\text { Materials and Processes }\end{array}$} & $\begin{array}{l}\text { Composites polymères } \\
\text { Polymer Composites }\end{array}$ \\
\cline { 2 - 2 } & $\begin{array}{l}\text { Ingénierie des matériaux polymères / } \\
\text { Polymer Materials Engineering }\end{array}$ \\
\cline { 2 - 2 } & $\begin{array}{l}\text { Mise en forme de poudres / } \\
\text { Powder Forming }\end{array}$ \\
\cline { 2 - 2 } & $\begin{array}{l}\text { Technologies de surface / } \\
\text { Surface Technologies }\end{array}$ \\
\hline \multirow{4}{*}{$\begin{array}{l}\text { Modélisation et instrumentation de procédés } \\
\text { Process Modelling and Instrumentation }\end{array}$} & $\begin{array}{l}\text { Techniques optiques / } \\
\text { Optical Techniques }\end{array}$ \\
\cline { 2 - 2 } & $\begin{array}{l}\text { Caractérisation et capteurs ultrasonores } / \\
\text { Characterisation and Ultrasonic Sensors }\end{array}$ \\
\cline { 2 - 2 } & $\begin{array}{l}\text { Modélisation numérique de procédés / } \\
\text { Numerical Modelling of Processes }\end{array}$ \\
\cline { 2 - 2 } & $\begin{array}{l}\text { Technologies intelligentes de formage / } \\
\text { Intelligent Forming Technologies }\end{array}$ \\
\hline Centre des technologies de l'aluminium / & Procédés de mise en forme de l'aluminium / \\
Aluminum Technologies Center & Aluminium Forming Processes \\
\hline
\end{tabular}

ご存じのように，CNRC/IMI があるケベック州はカナ ダで唯一フランス語が主に話されている地域である。それ ゆえ, 建物内での呼び出し, 電子メールによる連絡, スタッ フ間で交わされる日常会話はフランス語である。しかしな がら,フルタイムのスタッフ全員と, 小生を除く若干のパー トタイムのスタッフは英語とフランス語の両方を話すこと が出来る. 仮に, 1 週間以下の短い期間 $\mathrm{CNRC} / \mathrm{IMI}$ に滞 在するならば言葉の問題はほとんどないが, CNRC/IMI に 1 年以上滞在する場合には，フランス語を読み話す能力 が必要と思う。それにより，CNRC/IMIでの滞在はより 心地よいものになるだろうし，より有意義なものになるだ ろう.

\section{Polymer Composite グループでの 最近の研究トピックス}

Polymer Composite グループにおける最近の研究卜 ピックスについて紹介する。研究スタッフが発表した最近 の学会要旨や論文をひもといてみると, Polymer Compositeグループにおいて力を入れている研究トピックスとし て, 熱可塑性樹脂のナノコンポジットが挙げられる. 特に, 市販のポリマーと有機化クレーから作られるポリマー/ク レー系ナノコンポジットはおよそ 3 年前から活発に研究さ れている. ご存じのように，ポリマー/クレー系ナノコン ポジットは，ポリマーに少量のクレーを混ぜることにより， ヤング率や強度, バリア性, 難燃性, その他の特性が著し く向上する，近年注目されている材料の一つである。その 研究開発は，豊田中央研究所にてポリアミド $6 /$ モモリ ロナイトナノコンポジットが最初に開発されて以来，近年 急速に進んでいる. CNRC/IMIのホームページ上に本グ ループの紹介が書かれた PDFファイルがある。それには 以下の項目が“Research Activities”として紹介されている. （i ）特定の応用を目指したクレー表面改質技術の開発 （ii）溶融ブレンド技術によるナノコンポジットの作成 (iii）ポリマーコンポジットとナノコンポジットのブレン ド物の作成

（iv）ナノコンポジットの特性評価技術の開発

（v）ナノコンポジットの発泡

最近得られている成果を Proceeding や論文を引用しな がら紹介しよう. Polymer Compositeグループでは，市 販されているポリマーナノコンポジット（宇部興産で製造 されている PA-6ベースのナノコンポジット）を用いた基 礎研究が行われている. たとえば，溶融体の流動特性 ${ }^{2), 3)}$, PVT 特性 ${ }^{4}$, 内部構造と機械的特性との関係 ${ }^{5}$, 成形品の 亀裂成長 ${ }^{6}$, 疲労特性 ${ }^{7)}$, などがある。図 2 は $\mathrm{PA}-6 /$ クレー 系ナノコンポジットの定常状態におけるせん断速度とせん 断粘度との関係である ${ }^{3)}$. 図中の $t$ は “waiting time” と 呼ばれ， $t$ が大きいほど，測定の際に次のせん断速度のス

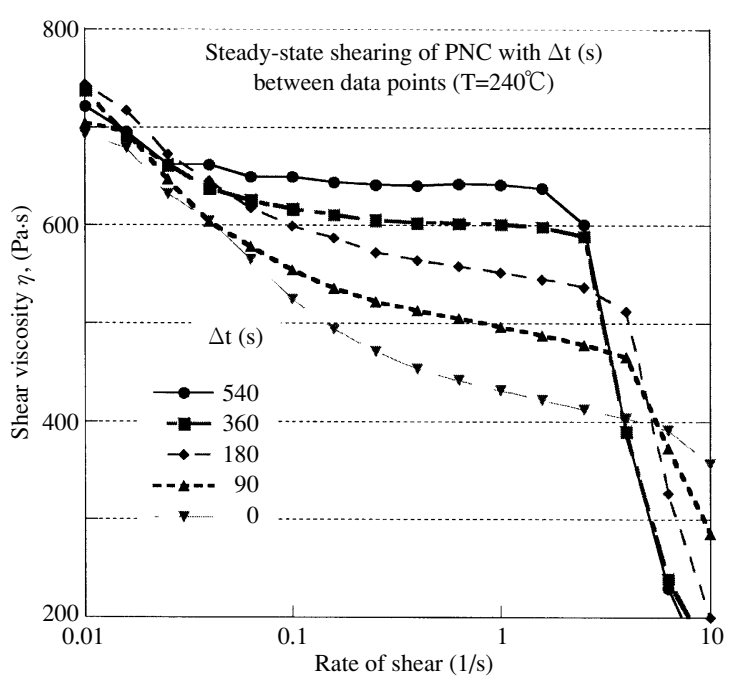

図 $2240^{\circ} \mathrm{C}$ における PA-6ナノコンポジットの定常せん 断粘度曲線 ${ }^{3}$. データ点の間は waiting time $\Delta t$ を 示し, 実験では $\Delta t=0 \sim 540 \mathrm{~s}$ 


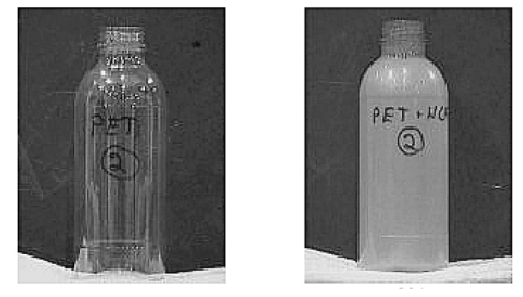

(a) 熱水を入れる前
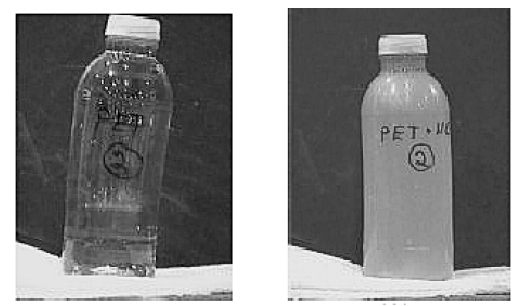

(b) $95^{\circ} \mathrm{C}$ の熱水を入れ、放置·冷却した後
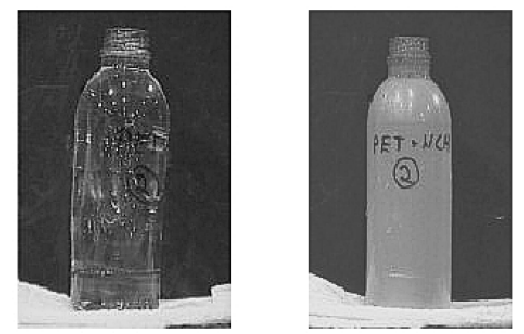

(c)Hot fill後、キャツプを開けた状態

図 3 ボトルの Hot fill 試験の結果. 各図面の左側が PET ボトル，右側が $3 \%$ ナノクレー含有 PET ボトル ${ }^{8)}$

テップに進むとき, 円板状のクレープレートがよりランダ ムな状態になっていることを示している．この図では，3 つの領域の存在が確認できる. 低いせん断速度ではせん断 粘度はせん断速度の増加と共に減少している. そのあと, 中程度のせん断速度の領域内でせん断粘度曲線の勾配が減 少する. $t$ が大きくなるとプラトーな領域が見られる. 特 に, $t=540 \mathrm{~s} に お け る$ 結果で顕著に見られる. そして高せ ん断速度領域では, せん断粘度は再びせん断速度の増加と 共に減少する。これは，高分子液晶のふるまいに似ており， 図 2 における三つの領域は Onogi らが 1980 年に発表した ネマチック液晶の性質と一致する。この現象は, 動的レオ ロジー試験の解析結果から見いだされ, 図 2 で示した定常 せん断流動特性試験, 応力成長の実験, フーリエ変換レオ

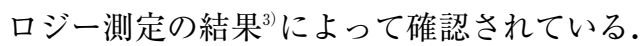

ナノコンポジットの応用の分野においても面白い結果が ある.ポリマーをベースとしたクレー系ナノコンポジット の特性の一つに, 成形品の熱変形温度の上昇がある. 図 3 は PET/クレー系ナノコンポジットと PET のみの hot-fill 試験の比較を示したものである ${ }^{8)}$. ボトルに $95^{\circ} \mathrm{C}$ の熱水を 満たし, キャップを閉め, 1 分間放置した後, 10 分間水水で 冷やすという試験である. PET ボトルは極端なくびれが 見られ，そのくびれはキャップを外したあとも残っている. これに対し， $\mathrm{PET} / ク レ ー$ 系ナノコンポジットのボトルは, 冷却したあと，わずかなくびれが見られ，キャップを外す ともとの形に戻る.この結果はポリマーに層状のクレーを 加えることで耐熱特性が改善されたことを示している.

このグループでは, 新規なナノコンポジットの開発にも

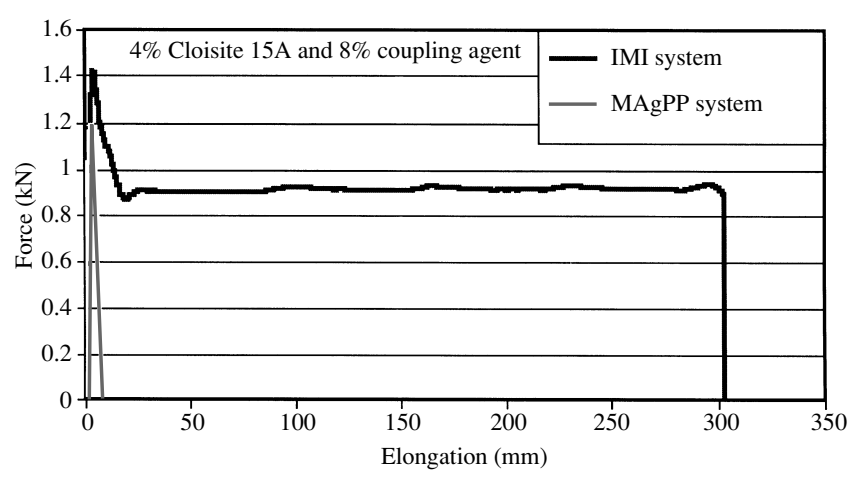

(a) SS曲線 (IMI systemがIMIで開発された材料)

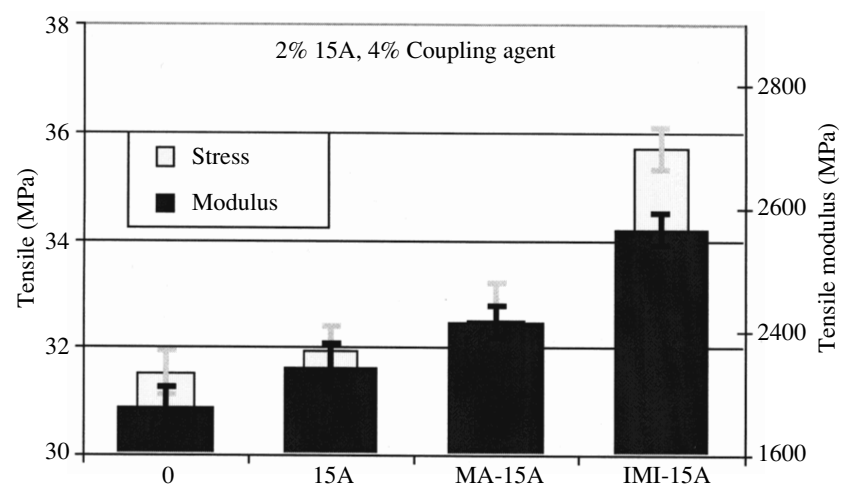

(b) 弾性率と強度 (IMI-15AがIMIで開発された材料)

図 4 IMI で開発された PP/クレー系ナノコンポジットと 他で発表されたナノコンポジットの引張特性の 比較 ${ }^{9)}$

取り組んでいる．特に，モンモリロナイトを用いたポリプ ロピレン系ナノコンポジットについては優れた成果が得ら れている。一般的に, ナノコンポジットの伸度はクレーの 含有率の増加と共に減少する. しかし, 本グループの一員 である Ton-That ら ${ }^{9)} に よ り$ 開発された新規な相溶化剂を 用いたポリプロピレン/クレー系ナノコンポジットは, 延 性と靱性が保持されている. 加えて, 強度とヤング率が公 開されている他のポリプロピレン/クレー系ナノコンポ ジットよりも上回っている. 図 4 に引張試験における比較 を示すが，CNRC/IMI で開発された材料が優れた特性を 示していることがわかる. CNRC/IMIにおけるナノコン ポジット・テクノロジーのさらなる有利な点は, 新しいナ ノコンポジットが二軸スクリュ押出機によるメルトコンパ ウンディングで作ることができることである．これは工業 的に他のナノコンポジットへの応用が期待される.

第 1 回ポリマーナノコンポジット国際シンポジウムが Polymer Composite Groupのメンバーが中心になって準 備され，2001 年 9 月に CNRC/IMI で開催された。このシ ンポジウムで発表された論文のうちいくつかがセレクトさ れ, Polymer Engineering and Science の特集号 (Vol.42, No. 9，2002）に掲載された. 次回のシンポジウム（第 2 回）は，2003 年 9 月に CNRC/IMI にて開催予定である. 詳細はウェブサイト〈http：//www.nanocomposites2003. com〉を参照されたい. ポリマー系ナノコンポジットに興 味のある方には，この学会への参加をおすすめする. 


\section{4.おわりに}

本稿では CNRC/IMI, Polymer Composite グループに ついて, 概要と最近の研究活動について紹介した. 本稿が 興味ある読者へのお役になれば幸いである.

小生の滞在期間中, Leszek A. Utracki 博士には, 研究 に関する数多くの貴重なご指導ご助言を賜り, 公私ともに 大変お世話になりました。ここに，心からの感謝とお礼を 申し上げます.また, グループリーダーの Johanne Denault 博士, 研究員の Tan Minh Ton-That博士, Martin N. Bureau 博士, その他 Polymer Composite グループや CNRC/IMI の皆様には小生の滞在に対し, 親切なサポー トをいただきました。ここに厚くお礼申し上げます。最後 に, 高分子成形加工で著名な研究者であり, Polymer Composite グループのメンバーであった Andres Garcia-Rejon 博士が 2002 年 3 月に亡くなられました. 博士は, 晚年ポ リマー/クレー系ナノコンポジットに関する研究を実施し, その一部を小生が CNRC/IMI 滞在中に実施しました。誌 面を借りて, 博士のご冥福をお祈り申し上げます。

\section{参 考 文 献}

1) Utracki, L. A. : 成形加工, 13, 110 (2001)

2 ) Utracki, L. A. and Lyngaae-Jørgensen, J. : Rheol. Acta, 41, 394 (2002)

3 ) Utracki, L. A., Sammut, P., and Lyngaae-Jørgensen, J. : Proceeding CD-ROM of PPS 2001 Taipei, I 16 (2002)

4 ) Simha, R., Utracki, L. A. and Garcia-Rejon, A. : Compos. Interfaces, 8, 345 (2001)

5 ) Bureau, M. N., Denault, J., Cole, K. C. and Enright, G. D. : Polym. Eng. Sci., 42, 1897 (2002)

6 ) Bureau, M. N., Denault, J. and Glowacz, F. : SPE ANTEC Tech. Papers, 2, 2125 (2001)

7 ) Bellemare, S. C., Bureau, M. N., Denault, J. and Ivan Dickson, J. : SPE ANTEC Tech. Papers, 2, 2235 (2002)

8 ) Garcia-Rejon A., Simard, Y. and DeGrandpre, C. : SPE ANTEC Tech. Papers, 1, 881 (2001)

9 ) Ton-That, M-T., Perrin, F., Laccand, P., Cole, K., Denault, J. and Enright, G. : Proceedings CD-ROM of Polymer Nanocomposites 2001 (2001)

\section{口文献抄録}

\section{Kunststoffe}

\section{- Vol. 91 (2001), No.1}

Steinhoff, W., Snyder, R. S. : EPDM-maBgeschneidert (p.90)

Grav, R. L. u. a.: Verbesserte Leistung-Phenolische Antioxidantien mit hoher Wirksamkeit und geringer Farbkontribution (p.94)

Albus, S. : Mit Wärme haushalten-Wärme-dämmung von Bauwerken (p.97)

Fries, K.-W.: Gut gedämmt-PUR-Metall-Dämm-elemente mit niedriger Wärmeleit-fähigkeit (p.102)

- Vol. 91 (2001), No.2

Altendorfer, F.: Chancen des Strukturwandels nutzen (p.18)

Kömpf, M. : Produzieren für die Medizintechnik (p.22)

Stützinger, C. : Hochleistung oder Flexibilität? (p.27)

Schöppner, V.: Barriereschnecken für eine breite Materialpalette (p.32)

Michaeli, W., Imhoff, A. : Auslegung von Einschnecken-extrudern (p.38)

Michaeli, W. u. a. : Auslegung von Spritzgießschnecken (p.42)

Aumüller, W. : Schälprufüng an 2-Komponenten-Bauteilen (p.46) 